\title{
Cysteinyl Leukotriene Receptor 2
}

National Cancer Institute

\section{Source}

National Cancer Institute. Cysteinyl Leukotriene Receptor 2. NCI Thesaurus. Code C143041.

Cysteinyl leukotriene receptor 2 (346 aa, $\sim 40 \mathrm{kDa}$ ) is encoded by the human CYSLTR2 gene. This protein is involved in the mediation of cysteinyl leukotriene-dependent signal transdution. 